\title{
Ranchers Vs. Ranchettes in California's Oak Rangelands
}

\section{Livestock grazing appears a viable - and useful - vegetation management tool in the Sierra Nevada Foothills.}

\author{
By Matthew J. Wacker and N. Maggi Kelly
}

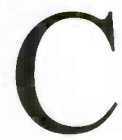

alifornia's oak savannas and woodlands have been the backbone of the state's rangeland livestock industry since the introduction of domestic livestock by Spaniards in 1769. In 1988, researchers at the California Department of Forestry estimated that the majority of these lands, approximately $90 \%$, were privately owned, with domestic livestock grazing about $80 \%$ of all oak rangelands.

Aside from their importance to the state's livestock industry, oak rangelands are one of the most biologically diverse habitats in the state. Because of these and other factors, such as a perceived lack of oak regeneration and the spread of diseases like sudden oak death, oak rangelands have become a major focus of concern in California during the last 20 years (the website http://danr.ucop.edu/ihrmp/ provides an overview of oak-related research and activities in the state).
Perhaps the greatest threat to oak rangelands is the conversion of these areas from ranching to large-lot (typically between 5 and 40 acre parcel sizes) residential uses. In a recent review published in 2001 by Rangelands, Jerry Holechek regarded the conversion of rangeland from livestock grazing to residential use as one of the most serious threats to the ecosystem services typically provided by rangelands. It is widely recognized that increases in residential development impair rangeland function, and the function of any ecosystem for that matter, through increased land fragmentation (14).

Perhaps less recognized are the impacts that land use change, particularly the increase in so-called exurban, or "ranchette," development has on vegetation community composition and structure.

Researchers at the University of California have identified differences in the management goals of

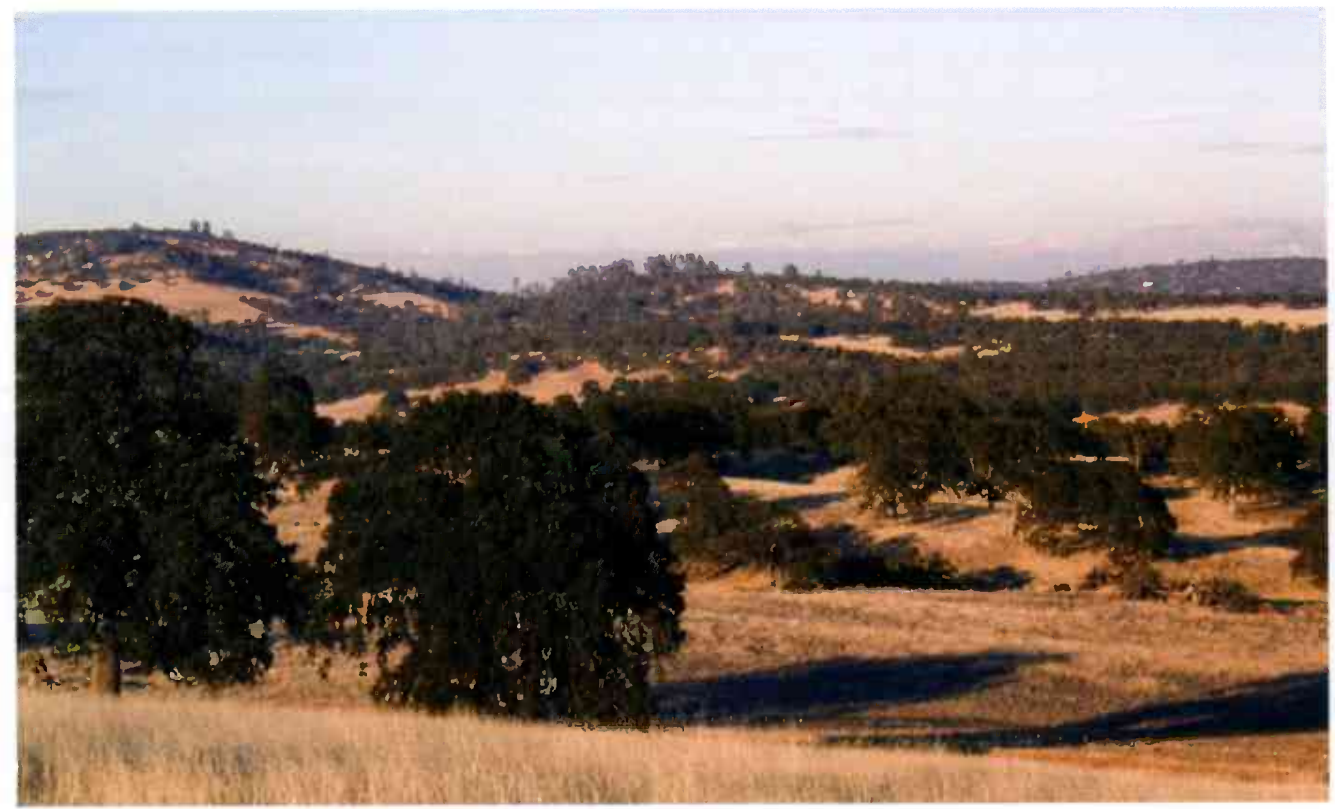

Typical California oak rangeland, (photo by M. Wacker). 
ranchers and exurbanites in California's oak rangelands that affect the type of vegetation community valued by these two groups $(5,9,10)$.

Generally speaking, exurbanites own and manage land for its amenity values while ranchers own and manage land for its productive value. In many of California's rapidly developing oak rangelands, the substitution of exurbanites' values for those of ranchers has led to widespread increases in tree canopy cover, increased cover of pine species within oak stands, and an overall decline of relatively open oak rangelands. Among the numerous potentially negative impacts, these changes in vegetation composition and structure can modify rangeland ecosystem function by increasing the probability of catastrophic wildfires (6) and reducing habitat quality for native plants and animals $(7,11)$.

We looked at approximately 50 years of oak rangeland vegetation and land use change data in $\mathrm{El}$ Dorado County located in the central Sierra Nevada foothills to determine the relationship between land use change and oak rangeland vegetation change in this rapidly growing exurban region. Beginning in $1942 / 1943$, we looked at large-scale vegetation changes on 30 ranches, 25 of which were subsequently sold and subdivided for residential use. We wanted to determine, relative to those parcels continuously managed by ranchers since the 1940s, if the shift to management by exurbanites affected the overall composition and structure of rangeland veg- etation and, therefore, the potential ecological function of these rangelands. We also offer some preliminary observations on the role of land use in oak rangeland vegetation succession.

\section{Oak Rangeland Vegetation Changes}

Our study area in western El Dorado County lies on the eastern edge of the Sacramento metropolitan area in the central foothills of the Sierra Nevada. This area has undergone widespread changes over the past 70 years with land used for livestock grazing declining from roughly $49 \%$ of the area in 1930 to $41 \%$ in 1957 to just $6 \%$ today.

At the same time, residential land use has increased from $0.2 \%$ in 1930 to $41 \%$ in 1957 to over $80 \%$ of the region today. The study area has consistently seen some of the fastest growth rates in the state. Over the last several decades the population has increased from roughly 20,000 in 1950 to almost 160,000 in 2000 (18). Much of this growth has come in the form of large-lot residential developments, typically of five to 10 acres in size.

Changes in vegetation composition resulting from this shift in land use were analyzed using two GIS datasets describing vegetation composition in the study area during the early 1940s and 1998. By using relatively simplistic GIS-based overlay techniques in Arc Info software we were able to obtain reasonably accurate estimates of land cover change

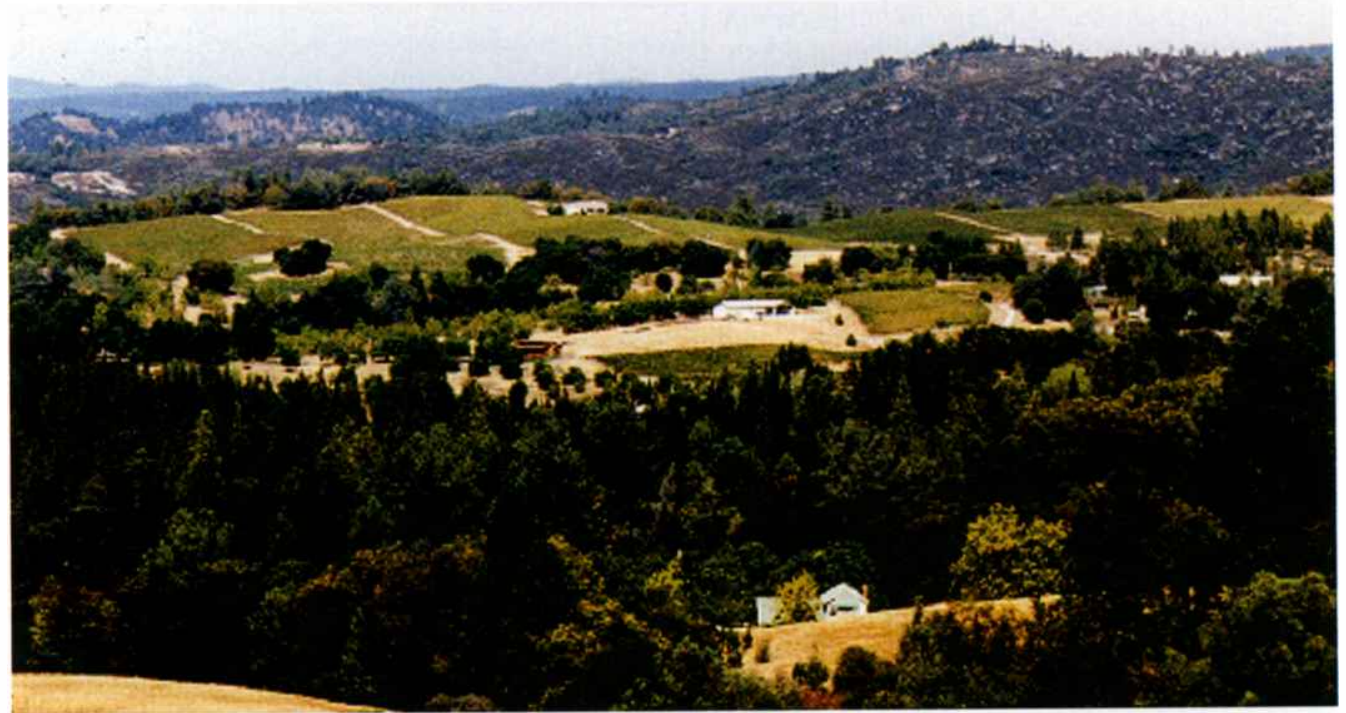

Current condition of many exurban El Dorado County oak rangelands. Notice the wide variety of vegetation types such as oak savanna, chaparral, and mixed oak-conifer woodlands and land uses such as large-lot residences and vineyards (photo by M. Wacker). 
over a large geographic area and a moderately coarse resolution.

Because the initial study area was so large, approximately 1,590 square kilometers, we limited our subsequent analysis to 30 different ranches. These ranches were chosen to minimize other factors such as soils, climate, and fire history that potentially could account for the observed vegetation changes. All the ranches were located in the western portion of the county in close proximity to one another where blue oak with an annual grass understory and mixed chaparral are the primary vegetation types.

Comparing historic (16) and current (3) land use datasets, we were able to identify which of our 30 initial ranches remained devoted to livestock grazing and which had been converted to residential uses. Vegetation polygons mapped on these parcels in 1942 or 1943 using aerial photography (17) were resampled using remotely sensed Thematic Mapper data from 1998 (15). Vegetation classes were compared based on land use (continuous ranching versus ranching switching to residential) and survey years. Vegetation was broken down into one of five different types as shown in Table 1. All data were analyzed using Chi-Square statistics to test differences among vegetation cover classes between land uses. Significance tests for proportions (20) were used to test differences in specific vegetation cover classes between land uses or sample years.

\section{Vegetation}

Table 2 compares vegetation conditions on our 30 sampled ranches in 1942/1943 as a function of future land use changes. Oak savannas were the primary cover type followed by shrub mix, grassland, and oak woodland; conifer mix types were relatively uncommon. Splitting these totals out based on whether or not the ranch would be subdivided in the future provided some additional information.

The initial differences in vegetation were highly significant between the two land use futures $\left(\chi^{2}<\right.$ $0.0001)$. This indicates that, although livestock were actively grazed on all 30 ranches in the 1940s, there were some distinct differences in the vegetation found on those ranches that, by 1998 , would be subdivided. Specific differences were more mixed conifer and grassland vegetation on the grazed ranches and more shrub mix vegetation on ranches that would eventually be sold and subdivided. It is important to note that there were no differences in the relative proportions of oak savanna and oak woodland vegetation between the two land use futures in 1942/1943.

\section{Vegetation}

Table 3 shows current vegetation composition on our 30 original ranches, only 5 of which were still used as cattle ranches by this time. Overall vegetation composition changed markedly from our initial

Table 1. Vegetation cover class descriptions.

Vegetation Class Description

Conifer mix Conifers dominant may or may not be mixed with lesser amounts of hardwoods and/or shrubs

Grassland Open grassland with less than $5 \%$ tree/shrub cover

Shrub mix

Oak Savanna

Oak Woodland

Shrubs dominant may or may not be mixed with lesser amounts of hardwoods and/or conifer

Less than or equal to $25 \%$ oak canopy cover, less than $5 \%$ shrub/conifer cover

Over $25 \%$ oak canopy cover, less than $5 \%$ shrub/conifer cover

Table 2. 1942/1943 vegetation segmented by future land use change. Asterisks indicate significance levels of proportion comparisons between land use futures $(* \mathrm{P}<0.01, * * \mathrm{P}<0.001$, *** $\mathrm{P}<0.0001)$.

\begin{tabular}{|c|c|c|c|c|c|c|c|}
\hline Land Use & & Conifer Mix & Grassland & Shrub Mix & Oak Savanna & Oak Woodland & Totals \\
\hline Ranching & $\begin{array}{l}\mathrm{n} \\
\%\end{array}$ & $\frac{12}{7 \%^{*}}$ & $\begin{array}{l}50 \\
29.1 \%\end{array}$ & 19 & $\begin{array}{l}64 \\
37.2 \%\end{array}$ & $\begin{array}{l}27 \\
15.7 \%\end{array}$ & $\begin{array}{l}172 \\
100 \%\end{array}$ \\
\hline \multirow[t]{2}{*}{ Ranch to Res. } & $\mathrm{n}$ & 34 & 205 & 320 & 516 & 161 & 1236 \\
\hline & $\%$ & $2.8 \%^{*}$ & $16.6 \%^{* * *}$ & $25.9 \%^{* * *}$ & $41.8 \%$ & $13.0 \%$ & $100 \%$ \\
\hline Totals & $\begin{array}{l}\mathrm{n} \\
\%\end{array}$ & $\begin{array}{l}46 \\
3.3 \%\end{array}$ & $\begin{array}{l}255 \\
18.1 \%\end{array}$ & $\begin{array}{l}339 \\
24.1 \%\end{array}$ & $\begin{array}{l}580 \\
41.2 \%\end{array}$ & $\begin{array}{l}188 \\
13.4 \%\end{array}$ & $\begin{array}{l}1408 \\
100 \%\end{array}$ \\
\hline
\end{tabular}


1942/1943 sampling. Interestingly, oak savannas remained the most common cover type and their total extent had not changed on our 30 initially sampled ranches, despite the fact that the majority of them had been sold and subdivided and were now used for residences. Additionally, the total extent of oak woodlands, although statistically significant, had only slightly increased.

Given past studies that have tended to find increasing canopy cover on many oak rangelands over time $(1,2,13,19)$ and the fact that many residential landowners manage their oaks to meet a wide variety of goals and amenity values this result

Table 3. Overall study area vegetation cover $1942 / 1943$ compared 1998 and significance levels of proportion comparisons.

\begin{tabular}{lccc}
\hline \hline Vegetation Class & $1942 / 43$ & 1998 & P-value \\
\hline Conifer Mix & $3.3 \%$ & $29.3 \%$ & $<0.0001$ \\
Grassland & $18.1 \%$ & $3.1 \%$ & $<0.0001$ \\
Shrub Mix & $24.1 \%$ & $8.9 \%$ & $<0.0001$ \\
Oak Savanna & $41.2 \%$ & $42.7 \%$ & ns \\
Oak Woodland & $13.4 \%$ & $16.0 \%$ & $<0.05$ \\
& & & \\
\hline
\end{tabular}

is somewhat surprising. The biggest change was for conifer mix types, which increased sharply from 1942/1943 and open grasslands, which saw a large decline; there was also a large drop in shrub mix types. Although we can make no conclusive statements regarding the causes of these observed vegetation changes, or whether or not they are related, we will attempt to develop some preliminary explanations in the next section.

Some of the changes shown in Table 3 become easier to understand when the land use histories of our 30 initial ranches are taken into account (Table 4). Comparing Table 2 with Table 4, several general trends are apparent. The relative distribution of different vegetation types is strongly related to land use history $\left(\chi^{2}<0.0001\right)$.

For example, the observed increase in conifer mix types and decline in shrub mix types is almost entirely associated with those ranches converted to residential use. The causal mechanisms behind this observation are very complicated; we discuss what relevant data we have below. Compared to 1942/1943, oak savanna types are now more common on grazed ranches compared to those ranches that have been developed but, similar to $1942 / 1943$ there is little difference in the relative amount of oak woodlands between our two classes of ranches. Finally, areas of open grassland saw similar declines on both ranch types; although, this very type is still much more common on our grazed ranches.

\section{Tracking the Changes: \\ Vegetation Change as a Function of Land Use History}

In 1951, ecologist Jack Major developed a conceptual model for understanding the origins of different types of vegetation. In this model, Major suggested that the formation of vegetation communities was related to several factors: regional climate, soil properties, topography, amount of time the vegetation community has had to develop, and source biota. The "source biota" factor specifically included human influences, through management activities like burning, logging, grazing, and so forth, on vegetation communities.

In the selection of our 30 study ranches, we tried to hold all factors, except for the human influence factor, relatively constant. All our ranches were generally found in the same elevational belt of the Sierra Nevada where the climate, soils, topography, and time factors, were relatively similar at the scale of individual ranches (generally 1,000 acres or more). Although we lack the detailed, site-specific vegetation and management history data to conclusively demonstrate cause and effect relationships between land use history and vegetation change, we can offer some educated guesses based on these broad similarities.

Based on our data, vegetation changes on California's oak rangelands is highly variable and appears, at least to some degree, to be related to land use history. Looking just at our sample ranches that remained in ranching during the study period, there were only a few observed changes, most of which follow existing models of vegetation succession in oak rangelands.

For example, grassland sites in 1942/1943 either remained as grasslands, or more commonly, transitioned into oak savannas. Oak savanna, oak woodland, shrub mixes, and conifer mixes tended to remain in these types. This supports the idea that ranchers generally have similar goals and values, i.e. the production of healthy livestock, and manage their lands accordingly. The end result is that vege- 
Table 4. The 1998 vegetation cover segmented by land use history. Asterisks indicate significance levels of proportion comparisons between land use histories $(* \mathrm{P}<0.01$, ** $\mathrm{P}<0.001$, *** $\mathrm{P}<0.0001$ ).

\begin{tabular}{|c|c|c|c|c|c|c|c|}
\hline Land Use & & Conifer Mix & Grassland & Shrub Mix & Oak Savanna & Oak Woodland & Totals \\
\hline $\begin{array}{l}\text { Ranching } \\
\text { Ranch to Res. }\end{array}$ & $\begin{array}{l}\mathrm{n} \\
\% \\
\mathrm{n} \\
\%\end{array}$ & $\begin{array}{l}17 \\
9.9 \%^{* * *} \\
395 \\
32.0 \%^{* * *}\end{array}$ & $\begin{array}{l}15 \\
8.7 \%^{* * *} \\
29 \\
2.4 \%^{* * *}\end{array}$ & $\begin{array}{l}20 \\
11.6 \% \\
106 \\
8.6 \%\end{array}$ & $\begin{array}{l}97 \\
56.4 \% \text { *** } \\
504 \\
40.8 \% \text { *** }\end{array}$ & $\begin{array}{l}23 \\
13.4 \% \\
202 \\
16.3 \%\end{array}$ & $\begin{array}{l}172 \\
100 \% \\
1236 \\
100 \%\end{array}$ \\
\hline Totals & $\begin{array}{l}\mathrm{n} \\
\%\end{array}$ & $\begin{array}{l}412 \\
29.3 \%\end{array}$ & $\begin{array}{l}44 \\
3.1 \%\end{array}$ & $\begin{array}{l}126 \\
8.9 \%\end{array}$ & $\begin{array}{l}601 \\
42.7 \%\end{array}$ & $\begin{array}{l}225 \\
16.0 \%\end{array}$ & $\begin{array}{l}1408 \\
100 \%\end{array}$ \\
\hline
\end{tabular}

tation composition, at least in this region, tends to be relatively stable on grazed rangelands.

However, if we look at the vegetation on those ranches that were sold, subdivided, and converted to residential uses the picture is significantly more complicated. Some rangeland vegetation types, like conifer mix types, are relatively stable, while most other types are highly dynamic. Similar to our grazed ranches, grassland sites frequently transitioned to oak savannas, but a variety of other transitions were observed as well. With most other vegetation types, transitions to conifer mix types appear to be the dominant trend although many other transitions were possible. It appears that many shrub mix stands were converted to conifer mix stands, but even more were converted into oak savanna or oak woodland stands. Most of the increase in conifer mix stands came from oak savanna stands, though many oak savannas transitioned into oak woodlands and shrub mix stands. Thus, the overall picture is fairly messy and difficult to interpret.

Assuming that management by ranchers modifies, in a consistent fashion, the successional tendencies of California's oak rangelands, once ranchers are taken out of the picture, the observed successional pathway of a given vegetation stand will be a function of the interaction between that stand's site potential, regional climate, and management. Without knowing when our study sites shifted from a ranch to a residential property it is impossible for us to know at what point along the successional continuum each vegetation stand occupies. Furthermore, we cannot tell whether this stand represents some end point or some intermediate step toward a final end point. However, in the absence of ranching, there appears to be a strong tendency for conversion of many oak rangeland vegetation types to conifer mixes, often along highly variable pathways.

\section{Conclusions}

We found that oak rangelands in the rapidly growing, exurban areas of western El Dorado County have undergone numerous changes in the last 50 years. Looking at our 30 ranches from the 1940s as a group, the absolute amount of oak savanna and oak woodland rangelands has remained relatively constant between the 40 s and the present. We found this trend despite the fact that the area has experienced rapid population growth and most of our study ranches have been sold and subdivided for residential development. However, comparing the relative amounts of different rangeland vegetation types between the five remaining ranches and the 25 ranches subdivided for residences, several important differences are apparent.

Most importantly, ranching tends to maintain open grassland and oak savanna habitats and to stabilize vegetation changes such that distinct vegetation stands tend to remain in the same or related vegetation states over several decades (i.e. grasslands remain grasslands or transition to oak savannas, oak savannas remain oak savannas, etc.).

Conversely, the conversion of rangelands from ranching to residential use tends to remove this stabilizing influence, resulting in vegetation changes and states that are a function of a myriad of interacting biological, physical, and human factors where the end product is not always predictable.

The ultimate result, although not readily apparent at this point, may be larger, denser, areas of mixed oaks, conifers, and shrubs that, among other things, raise catastrophic wildfire risks at the urban-wildland interface and reduce wildlife habitat quality. It seems clear that changes in vegetation composition and successional patterns accompanying the shift of oak rangelands from livestock grazing to subdivisions residences can have potentially negative con- 
sequences for the suite of ecosystem services provided by California's oak-dominated rangelands.

Thus, as oak rangelands across California continue to be converted from grazing to other uses, past patterns of vegetation change seen in El Dorado County may be seen elsewhere. The benefits of vegetation management by livestock grazing, combined with ecological and societal benefits realized from the preservation of large, unfragmented blocks of oak rangeland habitat, underscore the need to maintain livestock ranching as a viable land use on California's oak rangelands.

About the authors: Matt Wacker is a preserve manager and GIS specialist, Center for Natural Lands Management, Oroville, Calif., and Maggi Kelly is an Assistant Cooperative Extension Specialist, Department of Environmental Science, Policy, and Management, University of California, Berkeley, Calif. At the time of the research, the senior author was graduate research assistant, Department of Environmental Science, Policy, and Management, University of California, Berkeley.

Acknowledgements: This research was funded in part by a grant from the University of California Integrated Hardwood Range Management Program.

The authors would like to thank Louise Fortmann, Lynn Huntsinger, Al Sokolow, and Sarah Marvin for helpful criticism and feedback during various stages of this project.

\section{References}

1. Allen-Diaz, B. H. and B. A. Holzman. 1993. Resampling VTM plots in blue oak cover type series. Calif. Dept. of Forestry, Forest and Rangeland Resources Assessment Program Pub. 73. Sacramento, Calif.

2. Davis, F., R. Brown, B. Buyan and J. Kealy. 1995. Vegetation change in blue oak and blue oak/foothill pine woodland. Calif. Dept. of Forestry and Fire Protection, Forest and Rangeland Resource Assessment Program Pub. 34. Sacramento, Calif.

3. El Dorado County Assessor's Office. 2000. El Dorado County Parcel Plat Map and Assessor's Database (GIS Version). Placerville, Calif.

4. California Department of Forestry. 1988. California's Forests and Rangelands: Growing Conflicts Over Changing Uses. Forest and Rangeland Resource Assessment Program. Sacramento, Calif.
5. Fortmann, L. and L. Huntsinger. 1989. The effects of non-metropolitan population growth on resource management. Society and Natur. Resources. 2:9-22.

6. Greenwood, G. and S. Saving. 1999. Current and future patterns of development in El Dorado County. Calif. Dept. of Forestry and Fire Protection, Fire and Resource Assessment Program Pub. 27. Sacramento, Calif.

7. Hansen, A., R. Rasker, B. Maxwell, J. Rotella, J. Johnson, A. Wright, U. Langner, W. Cohen, R. Lawrence and M. Kraska. 2002. Ecological causes and consequences of demographic change in the New West. BioScience 52(2):51-168.

8. Holechek, J. 2001. A growing population, rangelands, and the future. Rangelands 23(6):39-43.

9. Huntsinger, L. and L. Fortmann. 1990. California's privately owned oak woodlands: owners, use, and management. J. Range Manage. 43(2):47-152.

10. Huntsinger, L., L. Buttolph and P. Hopkinson. 1997. Ownership and management changes on California hardwood rangelands: 1985 to 1992 . J. Range Manage. 50(4):423-430.

11. Maestas, J.D., R.L. Night and W.C. Gilbert. 2003. Biodiversity across nature reserves, ranches, and exurban developments. In: Proc. $56^{\text {th }}$ Annual Soc. Range Manage. Meeting. Casper, Wyo.

12. Major, J. 1951. A functional factorial approach to plant ecology. Ecology. 32:392-411.

13. Saah, D. 2001. Social and Environmental Change in the Sierra Nevada. M.S. Thesis, Univ. of Calif. Berkeley, Calif.

14. Saunders, D.A., R.J. Hobbs and C.R. Margules. 1991. The biological consequences of ecosystem fragmentation: a review. Cons. Biol. 5(1):18-32.

15. [CDF] California Department of Forestry and Fire Protection. 2000. Existing vegetation national forests. Fire and Resource Assessment Program. Sacramento, Calif.

16. Teegaurden, D., P. Cassamajor and J. Zivnuska. 1960. Timber marketing and land ownership in the Central Sierra Nevada region. University of California Division of Agricultural Sciences Pub. 71. Berkeley, Calif.

17. USDA 1949. Soil-vegetation maps. USDA Forest Service Pacific Southwest Forest and Range Exper. Station. Berkeley, Calif.

18. Wacker, M. 2002. Land Use and Vegetation Change on El Dorado County, California Rangelands: Implications for Rangeland Conservation. M.S. Thesis. Univ. of Calif. Berkeley, Calif.

19. Walker, P.A., S.J. Marvin, and L.P. Fortmann. 2003. Landscape changes in Nevada County reflect social and ecological transitions. Calif. Agr. 57(4):115-121.

20. Zar, J.H. 1998. Biostatistical Analysis, 4th ed. Prentice Hall, Upper Saddle River, N.J. 